UDC 532, 616.1

DOI: 10.20535/1810-0546.2017.2.99724

\author{
I. Nesteruk ${ }^{1,2^{*}}$, A. Redaelli ${ }^{3}$, I. Kudybynn ${ }^{1,2}$, F. Piatti ${ }^{3}$, F. Sturla ${ }^{3}$ \\ ${ }^{1}$ Institute of Hydromechanics of NASU, Kyiv, Ukraine \\ ${ }^{2}$ Igor Sikorsky KPI, Kyiv, Ukraine \\ ${ }^{3}$ Politecnico di Milano, Milan, Italy
}

\title{
GLOBAL AND LOCAL CHARACTERISTICS OF THE BLOOD FLOW IN LARGE VESSELS BASED ON 4D MRI DATA
}

Background. Magnetic resonance imaging (MRI) using three-dimensional velocity encoding phase contrast (PC) methods offers the opportunity to quantify time-resolved 3D flow patterns in vivo. This technique can have a breakthrough impact on the evaluation, risk stratification and surgical planning in hemodynamic-related pathologies, e.g., cardiac valve diseases, arterial stenos or insufficiency, aortic dilation, dissection or coartaction. However, its applicability in clinics is limited due to the complex post-processing required to extract the information and the difficulty to synthesize the obtained data into clinical useful parameters.

Objective. In this work, a software tool is presented which analyzes the row data and provides information along the whole vessel, between two selected cross-sections and in the vicinity of the selected points.

Methods. A fully automatic algorithm based on the properties of the steady Hagen-Poiseuille flow was developed which in few minutes segments the vessel shape, visualize the blood flow and calculates its characteristics. Since the time and space resolutions of the data are limited, we avoid the differentiation of the velocity field.

Results. The algorithm has been tested on datasets of patients with bicuspid aortic valve and healthy volunteers. Results are provided both as maximum and time-averaged values in aorta, pulmonary artery, left and right ventricles.

Conclusions. The results demonstrate that the presented approach could be useful for medical doctors in order to classify and stratify different valve and/or vessel pathologies.

Keywords: 4D flow; MRI; bicuspid valve; aortic flow; vessel pathologies.

\section{Introduction}

The MRI data can be an effective tool for the unsteady blood flow investigations in aorta and large vessels. (see, e.g., [1-5]). These characteristics ensure large enough number of points in the aorta or the ventricle cross section to analyse the flow patterns and their changes in time.

The problem is to extract the points located inside the vessel from the regular MRI grid, since the level of signal outside the aorta can be comparable and even grater than inside the vessel. For the time averaged data, the level of noise is smaller but can still exceed the values of velocity components inside the vessel.

The user-friendly tools need to segment the vessel shape and to estimate the blood flow characteristics with minimum of manual operations. For example, it is a need to avoid manual selecting the points located on or near to the vessel boundaries on each of MRI slices, since this procedure (used in many existing algorithms) is very time-consuming and labour expensive.
In our paper, we will describe an origin algorithm, which automatically selects the points located inside the vessel, visualize the flow patterns at different flow sections and different moments of time, calculate the radius and area of the vessel cross sections, the velocity components, flow rates, flow jet angles etc. and estimate the wall shear stresses.

\section{Problem formulation}

Development and testing an automatic algorithm for segmentation of large vessels and calculation the general and local characteristics of the blood flow with the use of 4D MRI data.

\section{Materials and Methods}

Steady Hagen-Poiseuille flow. We shall use the properties of the steady Hagen-Poiseuille flow in the cylindrical pipe of radius $R$ (see, e.g., [6]) to select the MRI grid points, located inside aorta. The local velocities of this flow are directed along the pipe axis and its magnitude $U$ depends on the radial distance

\footnotetext{
* corresponding author: inesteruk@yahoo.com

${ }^{* *}$ The authors gratefully acknowledge the support of the project AMMODIT funded within EU H2020-MSCA-RICE
} 
from the axis $r$, dynamic viscosity coefficient $\mu$ and the pressure gradient $d p / d x$ along the pipe axis:

$$
U=-\frac{1}{4 \mu} \frac{d p}{d x}\left(R^{2}-r^{2}\right) .
$$

Usually we don't know the real values of the blood viscosity and the pressure gradient. But we can use the mean velocity $u$ averaged at a cross section of the pipe

$$
u=\frac{2}{R^{2}} \int_{0}^{R} r U d r=-\frac{R^{2}}{8 \mu} \frac{d p}{d x}
$$

and the dimensionless velocity (with the use of (1) and (2)):

$$
U / u=2\left[1-(r / R)^{2}\right]
$$

in order to compare the real flow in the aorta cross section and the steady Hagen-Poiseuille flow.

To compare the real wall shear stresses with the values typical for the steady Hagen-Poiseuille flow let us calculate

$$
\tau=-\left.\mu \frac{d U}{d r}\right|_{r=R}=-\frac{R}{2} \frac{d p}{d x}
$$

and the dimensionless characteristics

$$
\bar{\tau}=\frac{\tau R}{\mu u}=-\left.\frac{d(U / u)}{d(r / R)}\right|_{r=R}=4
$$

A principle of segmentation. Formula (1) is an exact solution of the Navier-Stokes equation and is valid at any Reynolds number $R e=2 R u / v$ ( $v$ is the kinematic viscosity). But at high values of the Reynolds number $(\operatorname{Re}>2300)$ the real flow becomes unstable and turbulent, [6]. In the case of aorta with typical values of the blood viscosity $\mu=3 c P$, the flow rate $Q=0.25 u d^{2}=51 / \mathrm{min}$ and diameter $d=2 R$ $=20 \mathrm{~mm}$ the Reynolds number can be estimated as $\mathrm{Re} \approx 1800$. Thus, we can expect to have the laminar flow (1) at some moments of the cardiac cycle and to have it for the time-averaged values of the normal velocities at the cross-sections of aorta and other vessels.

The algorithm of the segmentation is based on this idea. For a given point inside the vessel, the nearest point of the MRI grid was found. Since in the cross-section of the vessel all velocities are directed along its normal (see (1)), the corresponding cross-section, the nearest points of the grid with the similar directions of the velocity can be found and the center of the cross-section can be calculated. The next point inside the vessel can be calculated by small moving along the normal from the center of the cross-section (up- or downstream of the blood flow). By repeating the previous procedure, all points of MRI grid located inside the vessel can be extracted and the characteristics of the blood flow can be calculated. We have used the time averaged data and the instant velocity components at the maximum flow rate to segment the vessels.

\section{Results and discussion}

Comparison of the results based on the instant and the time averaged data. The use of time averaged (during the complete cardiac cycle) velocities and the velocity components of the at the moment of maximum systole (maximum flow rate) yields similar results for the shape and flow characteristics, see Figs. 1-3.

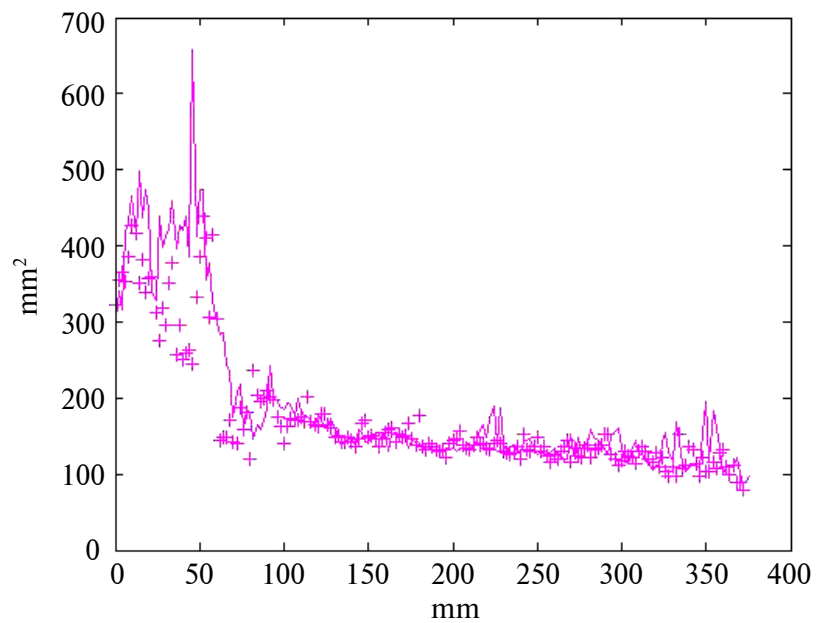

Fig. 1. The area of the aorta sections versus longitudinal distance along the aorta centre line. Time averaged data are shown by line, instant values are represented by crosses

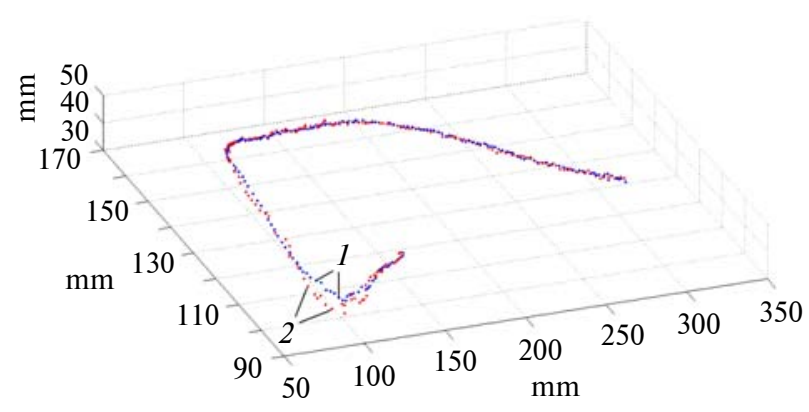

Fig. 2. Centre lines of the aorta cross sections: 1 - time averaged data, $2-$ instant values 


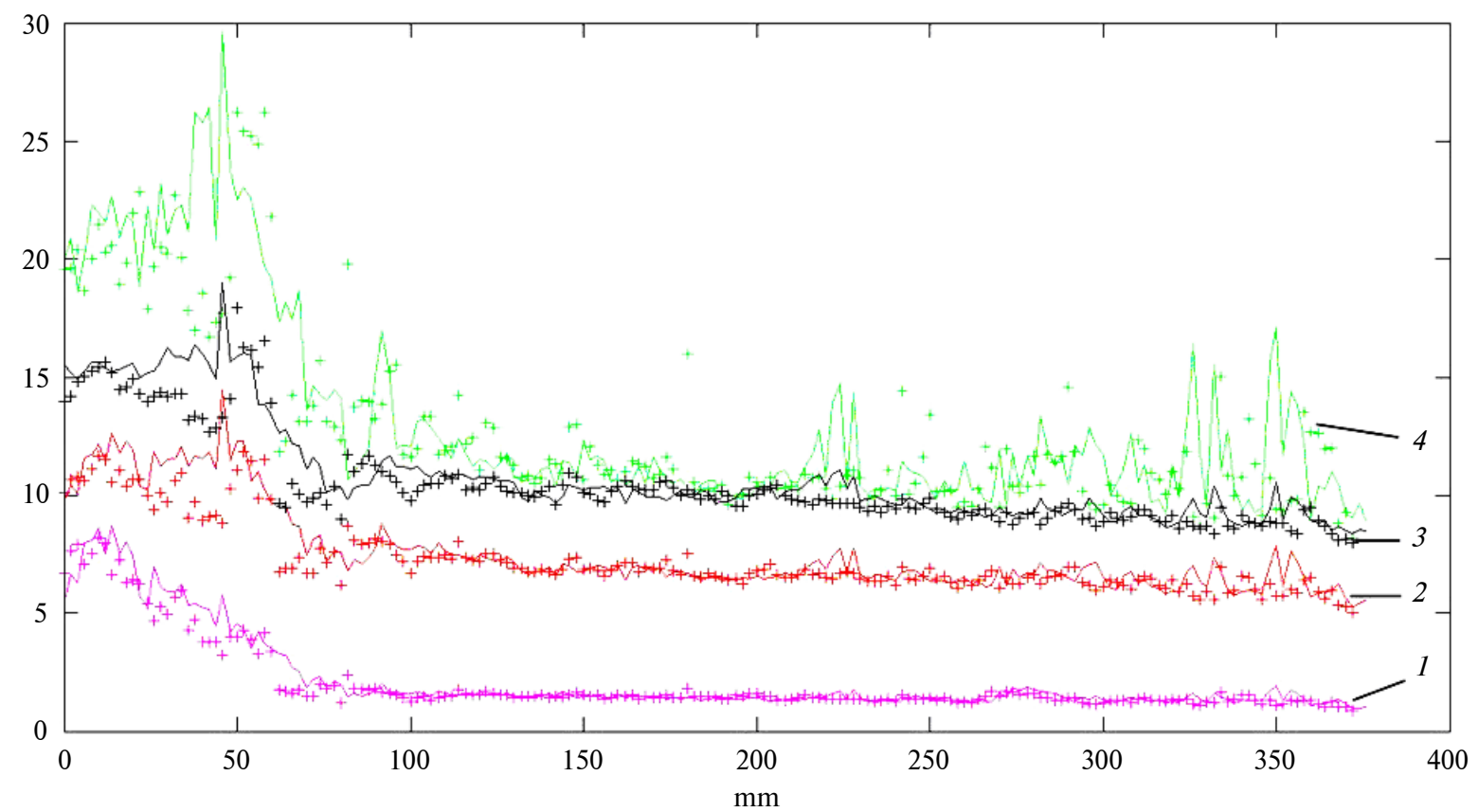

Fig. 3. The radii of the cross sections in $\mathrm{mm}$ and the flow rate in $1 / \mathrm{min}(1)$ versus longitudinal distance along the aorta centre line in mm. Maximum radius (4), the averaged for the circle values (3) and averaged with the use of real area of the cross section (2). The lines show time averaged data; crosses represent the results obtained with the use maximum systole velocity components

Flow patterns at different moments of time. The analysis of the flow patterns at one cross-section in different moments of the cardiac cycle showed that regular flow similar to the distribution (1) occurs only at the maximum systole (the maximum flow rate). The examples are shown in Figs. 4 and 5 for a one cross-section located in the aorta arch (Fig. 6, a). Fig. 4 illustrates that at maximum systole the dimensionless velocities ("circles") are rather close to the

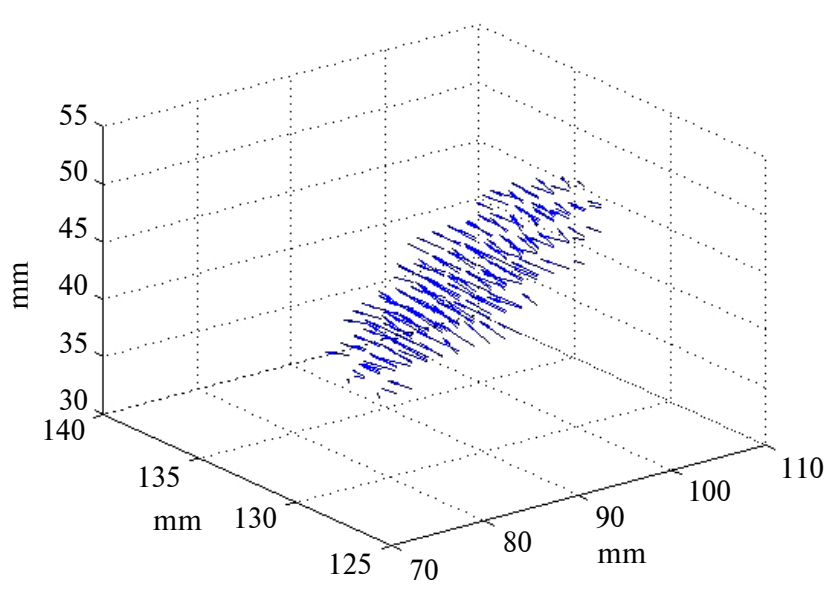

$a$ theoretical distribution (3) (show in Figs. 4 and 5 by solid line) and the largest component of the velocity is the normal one. The points in Fig. 5 show that at diastole the flow is very chaotic and differs from the theoretical curve (3).

In order to decide is the blood flow swirling it is enough to calculate the average transversal velocity with the use of all points in a cross-section. This simple procedure allows avoiding the different

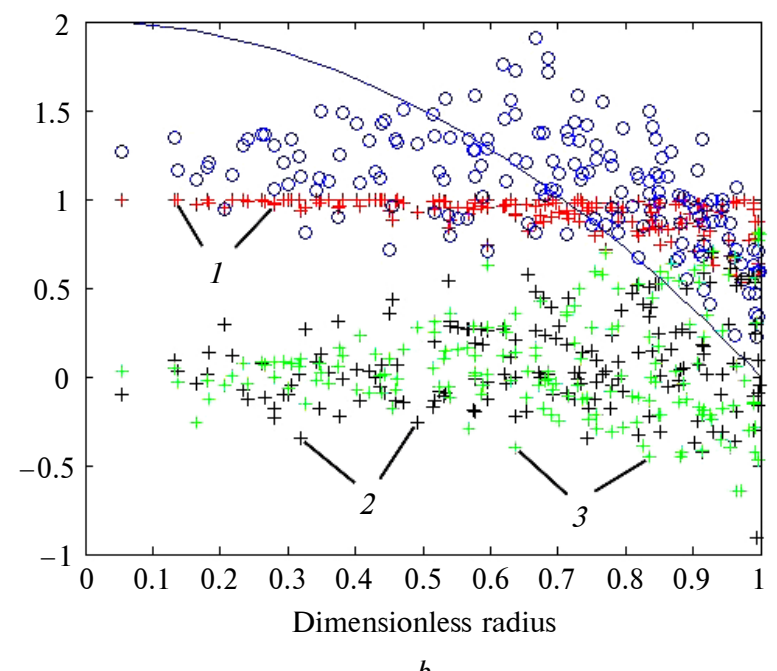

Fig. 4. Maximum systole at an aorta arch cross-section. Example of the flow pattern $(a)$ (all coordinates are in mm) and dimensionless magnitude of the local velocity $(b)$ based on $u$ (circles) and based on the local magnitude of the velocity, the normal $(1)$, the radial (2) and transversal (3) velocities versus the radial distance from the cross-section center (based on its radius) 

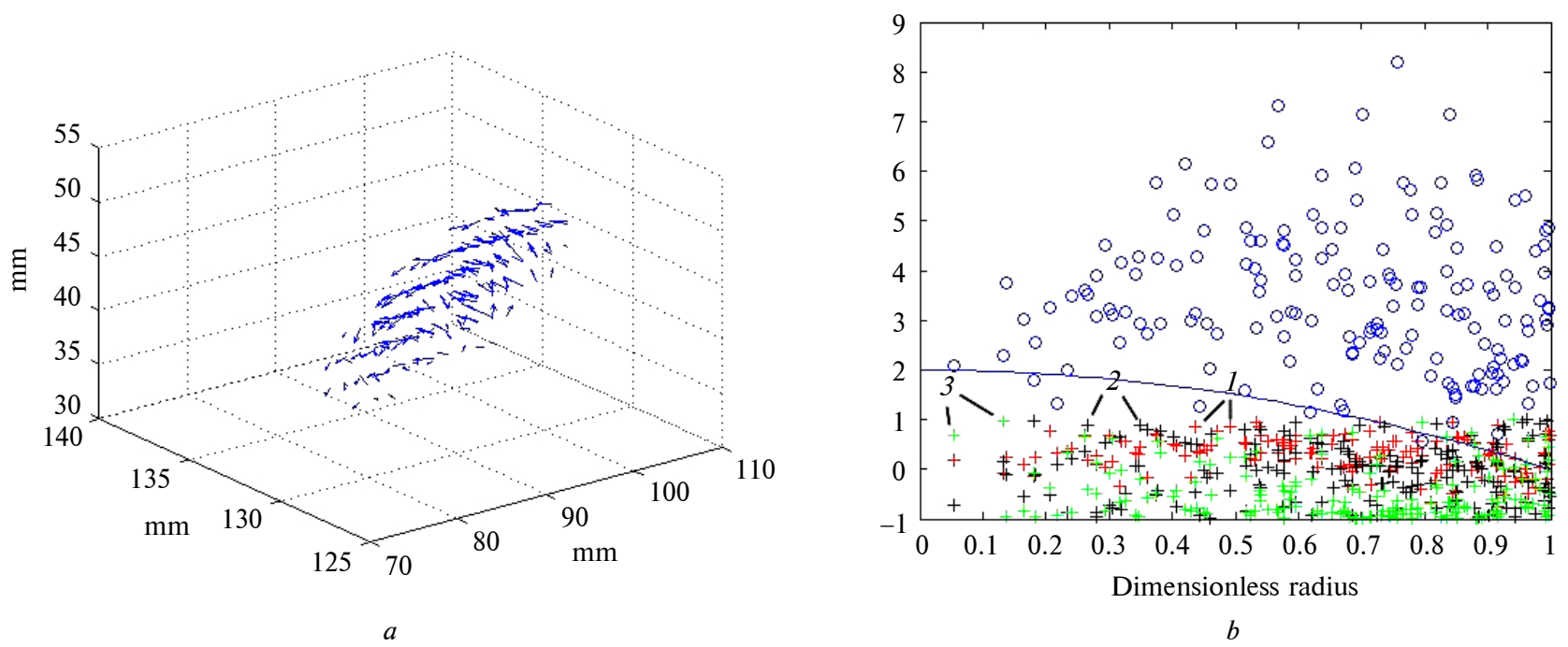

Fig. 5. Diastolic flow pattern at the aorta cross-section shown in Fig. 4. Example of the flow pattern (a) (all coordinates are in mm) and dimensionless magnitude of the local velocity $(b)$ based on $u$ (circles) and based on the local magnitude of the velocity, the normal (1), the radial (2) and transversal (3) velocities versus the radial distance from the cross-section center (based on its radius)

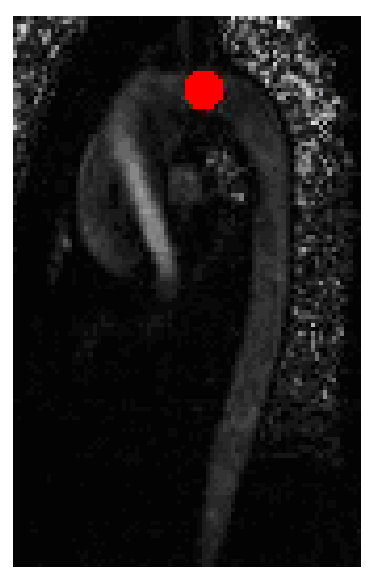

$a$

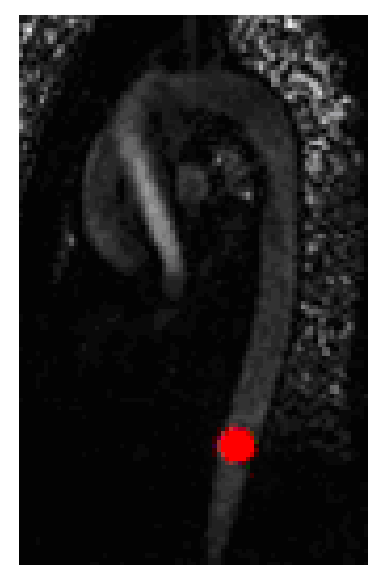

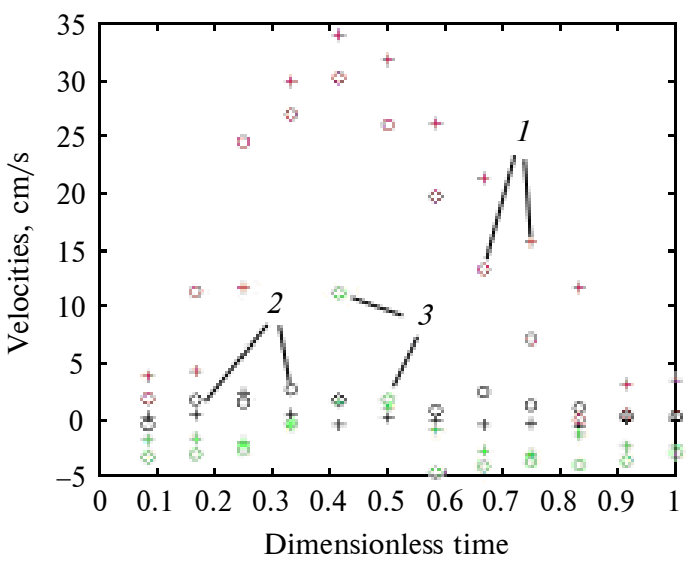

$c$

Fig. 6. Average values of velocity components $(\mathrm{cm} / \mathrm{s})$ versus dimensionless time (based on the duration of the cardiac circle) $(c)$ in two cross-sections in the arch $(a)$ and descending aorta $(b)$. Normal (1), radial (2) and transversal (3); aorta arch - circles, descending aorta - crosses

tiation of the velocity filed, which is necessary to calculate the helicity $[2,3]$. The results presented in Fig. 6 show that in the aorta arch the blood flow is rather swirling at the maximum systole. At other moments of time the space averaged transversal velocity is smaller and has opposite direction. In the descending aorta the swirling is much smaller.

The values averaged by time and space are presented in Table. It can be seen that radial and transversal components of the velocity are more than ten times smaller than the normal one. Since the radial velocity averaged by time and space must be close to zero at every section, the values presented in Table illustrate the accuracy of measurements and segmentation.
Table. Values averaged by time and space

\begin{tabular}{|c|c|c|}
\hline Values & Aorta arch & $\begin{array}{c}\text { Descending } \\
\text { aorta }\end{array}$ \\
\hline Normal velocity $(\mathrm{cm} / \mathrm{s})$ & 13.5 & 16.4 \\
\hline Flow rate $(1 / \mathrm{min})$ & 3.7 & 2.5 \\
\hline Radial velocity $(\mathrm{cm} / \mathrm{s})$ & 1.2 & 0.12 \\
\hline Transversal velocity $(\mathrm{cm} / \mathrm{s})$ & -1.6 & -1.34 \\
\hline
\end{tabular}

Examples of vessel segmentation. To segment the aorta or the pulmonary artery we need to select only one point located inside the vessel as shown in left parts of Figs. 7 and 8. The developed MATLAB 
code needs $10-12 \mathrm{~s}$ of $\mathrm{PC}$ time to select the points of the MRI grid located near one vessel cross-section and calculate the parameters of the blood flow. Known algorithms need to select some points (5-6) on the vessel boundary at every MRI data slice and yield similar vessel shapes. We have tested the algo- rithm with the use of 25 data sets obtained for BAV affected and healthy patients.

Global and local flow patterns and flow characteristics at different moments of time. The algorithm allows visualizing the flow in the whole vessel (Fig. 9), between two selected points (Fig. 10) or near a selected point (Fig. 11) at different moments of time.

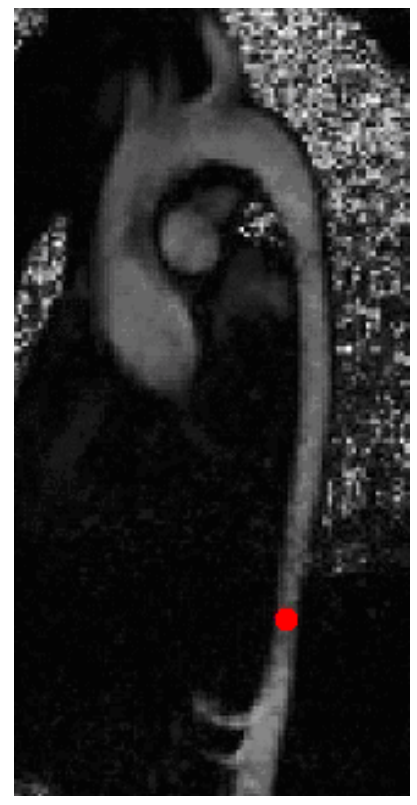

$a$

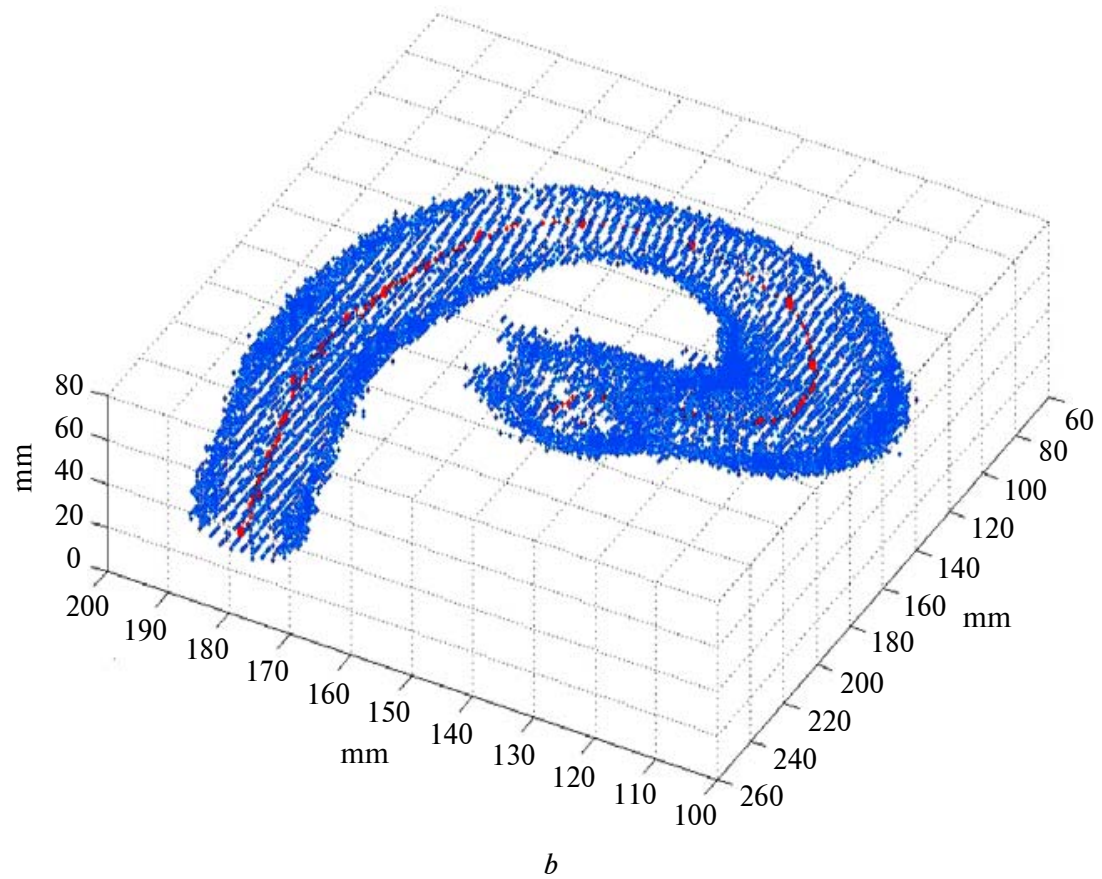

Fig. 7. Segmentation of the aorta and the left ventricle with the use of one point selected manually inside the aorta (a) and data corresponding to the maximum systole $(b)$

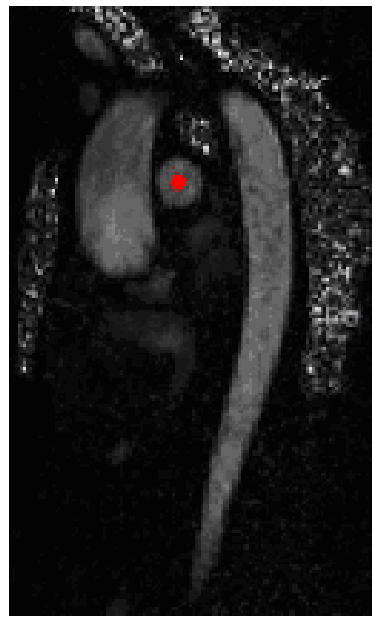

$a$

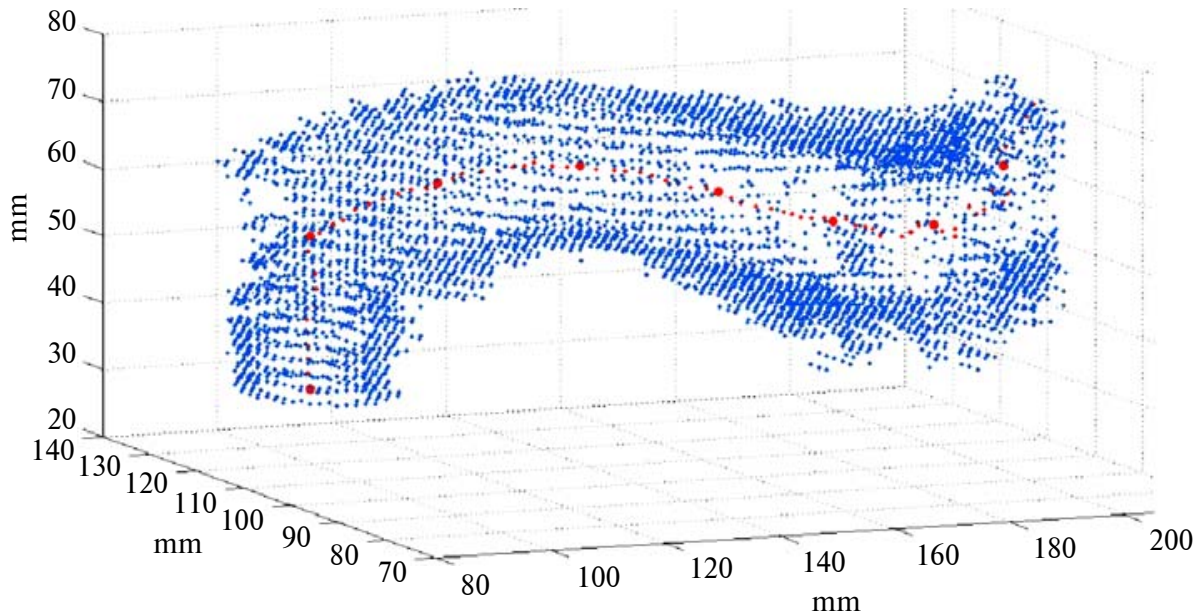

$b$

Fig. 8. Segmentation of the pulmonary artery and right ventricle with the use of one point selected manually inside the pulmonary artery $(a)$ and data corresponding to the maximum systole $(b)$ 

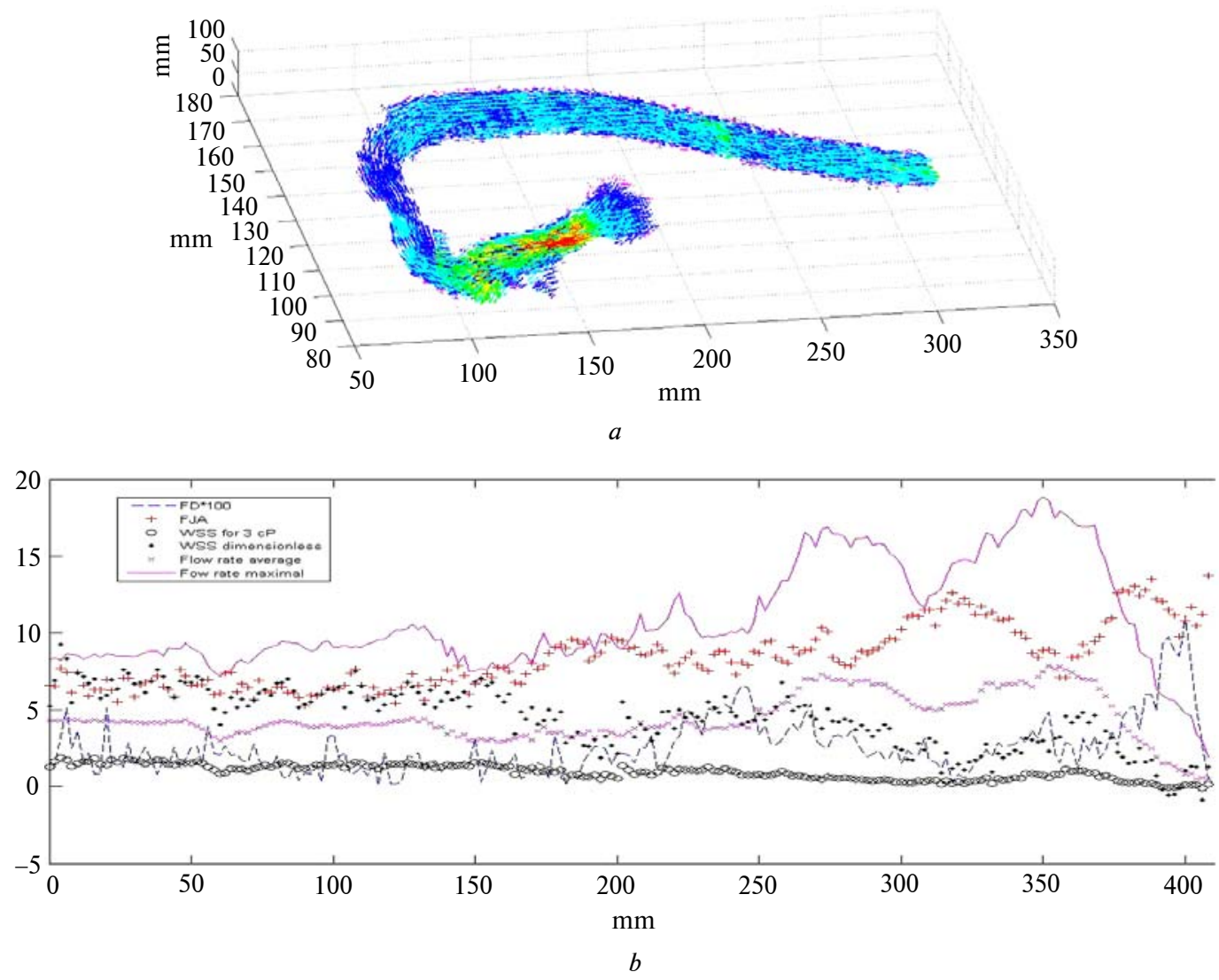

Fig. 9. The flow pattern in the left ventricle, aortic valve and aorta at the maximum systole (a); the flow displacement (FD), the flow jet angle (FJA), wall shear stress (WSS) dimensionless (eq. (4)) and calculated with the use of the blood viscosity $3 \mathrm{cP}$ (in Pa) $(b)$, maximal and average flow rates in $1 / \mathrm{min}$ are shown versus the distance from the last cross-section in the descending aorta along the centre line in $\mathrm{mm}$

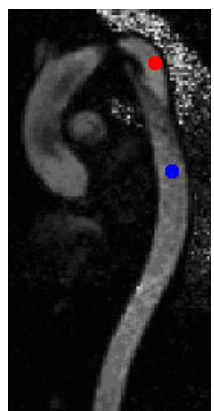

$a$

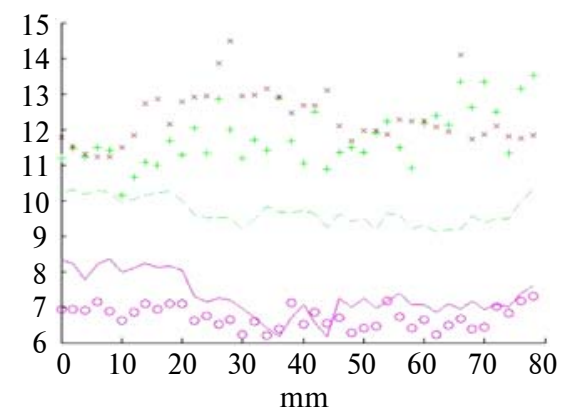

$b$

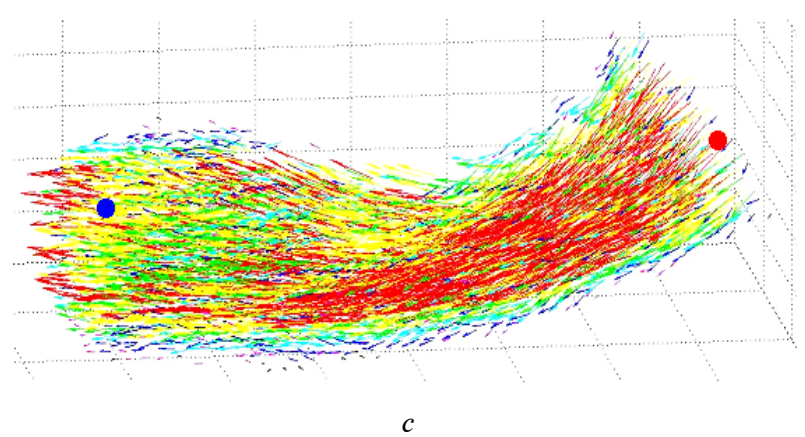

Fig. 10. The flow pattern $(c)$ and flow characteristics between two selected points in aorta at the maximum systole $(a)$; the radii averaged with the use of different approaches $(b)$ are shown by lines and crosses, the maximum radius by "crosses" (all in $\mathrm{mm}$ ), the maximal velocity in decimetre/sec are presented by " $\times$ " markers versus the distance along the centre line in $\mathrm{mm}$ 


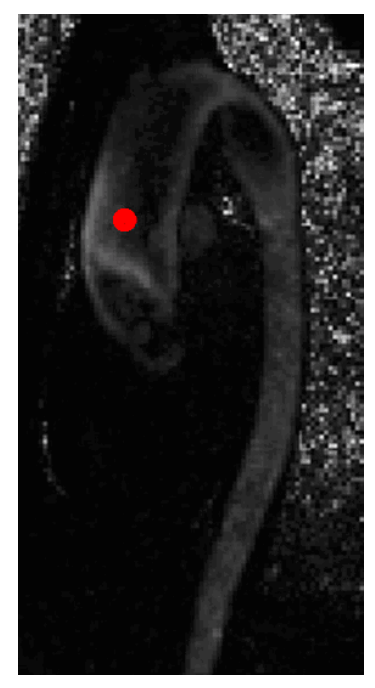

$a$
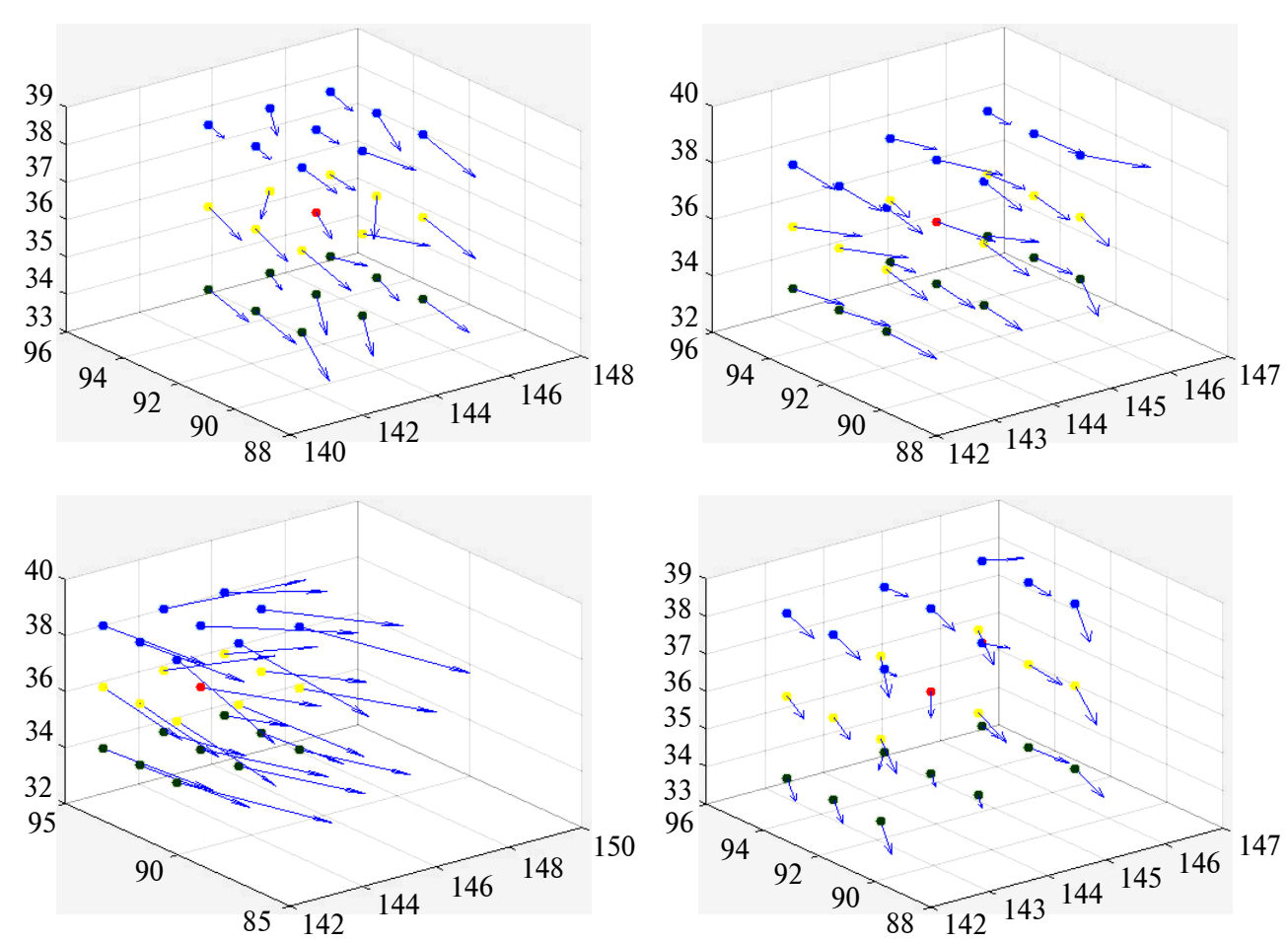

$b$

Fig. 11. The blood flow vectors near a selected point $(a)$ at different moments of time $(b)$ (all coordinates are in mm)

\section{Conclusions}

A fully automatic algorithm based on the properties of the steady Hagen-Poiseuille flow was developed to segment the vessel shape, to visualize the blood flow and to calculate its characteristics.

The algorithm has been tested on 25 datasets of patients with bicuspid aortic valve and healthy volunteers. Results are provided both as maximum and time-averaged values in aorta, pulmonary artery, left and right ventricles. The results demonstrate that the presented approach can be used in clinics by medical doctors in order to classify and stratify different valve and/or vessel pathologies.
The developed algorithms have to be integrated in a user-friendly tool and tested with the use of multiple data sets in order to select the most important characteristics for diagnostics of different pathologies of the heart and large vessels.

\section{Acknowledgment}

The study was supported by EU-financed Horizon-2020 project AMMODIT (Grant Number MSCA-RISE 645672).

\section{References}

[1] M.A. Bernstein et al., Handbook of MRI Pulse Sequences. Elsevir, Academic Press, 2004.

[2] U. Morbiducci et al., "In vivo quantification of helical blood flow in human aorta by time-resolved three-dimensional cine phase contrast”, Ann. Biomed. Eng., vol. 37, no. 3, 2009, pp. 516-531. doi: 10.1007/s10439-008-9609-6

[3] U. Morbiducci et al., "Mechanistic insight into the physiological relevance of helical blood flow in the human aorta: an in vivo study”, Biomech. Model Mechanobiol., vol. 10, no. 3, pp. 339-355, 2011. doi: 10.1007/s10237-010-0238-2

[4] F. Piatti et al., "Towards the improved quantification of in vivo abnormal wall shear stresses in BAV-affected patients from 4D flow imaging: Benchmarking and application to real data”, J. Biomech., vol. 50, pp. 93-101, 2017. doi: 10.1016/ j.jbiomech. 2016.11.044

[5] I. Nesteruk and A. Redaelly, "Cooperation between Politecnico di Milano and Institute of Hydromechanics NASU in frames of EUMLS project”, in Proc. AMMODIT and final EUMLS Workshop, Mathematics for Life Sciences, Hasenwinkel, Germany, March 07-11, 2016, pp. 18-19.

[6] L.G. Loitsyanskiy, Mechanics of Liquids and Gases, 6th ed. New York and Wallingford: Begell House, 1995. 
І.Г. Нестерук, А. Редаеллі, І.Б. Кудибин, Ф. П'ятті, Ф. Стурла

ГЛОБАЛЬНІ ТА ЛОКАЛЬНІ ХАРАКТЕРИСТИКИ ТЕЧІЇ КРОВІ У ВЕЛИКИХ СУДИНАХ, ЩО БАЗУЮТЬСЯ НА ЧОТИРИВИМІРНИХ ДАНИХ МРТ

Проблематика. Магнітно-резонансна томографія, що використовує методи фазового контрасту для визначення трьох компонент швидкості, дає змогу in vivo отримати числову інформацію про зміну в часі тривимірних течій. Ця технологія може мати вирішальний вплив на оцінювання, визначення ризиків і планування хірургічного втручання при патологіях кровообігу, наприклад при захворюванні клапанів серця, артеріальних стенозах або недостатності, дефрормації, розшаруванні чи звуженні аорти. Однак її клінічне застосування є обмеженим через складну обробку даних, необхідну для виділення інформації, та проблеми синтезу отриманих даних у клінічно корисні параметри.

Мета дослідження. В роботі представлений програмний продукт, що аналізує первинні дані і надає інформацію вздовж всієї судини, між двома вибраними перерізами та в околі вибраних точок.

Методика реалізації. Розроблено повністю автоматизований алгоритм, що спирається на властивості течії ГагенаПуазейля та в лічені хвилини виділяє форму судини, візуалізує течію крові та розраховує їі характеристики. Оскільки роздільна здатність даних у просторі та часі є обмеженою, ми уникаємо диференціювання поля швидкостей.

Результати досліджень. Алгоритм протестований на даних пацієнтів із двостулковим аортальним клапаном та здорових добровольцях. Наведено результати для максимальних та усереднених у часі значень в аорті, легеневій артерії, лівому і правому шлуночках.

Висновки. Результати показують, що запропонований підхід може бути корисним для медиків для класифрікації та діагностики різних патологій клапанів і судин.

Ключові слова: чотиривимірний потік; двостулковий клапан; течія в аорті; патології судин.

И.Г. Нестерук, А. Редаелли, И.Б. Кудыбин, Ф. Пьятти, Ф. Стурла

ГЛОБАЛЬНЫЕ И ЛОКАЛЬНЫЕ ХАРАКТЕРИСТИКИ КРОВОТОКА В БОЛЬШИХ СОСУДАХ, ОСНОВАННЫЕ НА ЧЕТЫРЕХМЕРНЫХ ДАННЫХ МРТ

Проблематика. Магнитно-резонансная томография, использующая методы фразового контраста для определения трех компонент скорости, позволяет in vivo получить числовую информацию о временных изменениях трехмерных течений. Эта технология может иметь решающее влияние на оценку, определение рисков и планирование хирургического вмешательства при патологиях кровотока, например при болезнях сердечных клапанов, артериальных стенозах или недостаточности, деформации, рассечении или сужении аорты. Однако ее клиническое использование ограничено из-за сложной обработки данных, необходимой для выделения информации, и проблемы синтеза полученных данных в клинически полезные параметры.

Цель исследования. В работе представлен программный продукт, анализирующий исходные данные и представляющий информацию вдоль всего сосуда, между двумя выбранными сечениями и в окрестности выбранных точек.

Методика реализации. Разработан полностью автоматизированный алгоритм, основанный на свойствах течения ХагенаПуазейля и в считанные минуты выделяющий фрорму сосуда, визуализирующий кровоток и рассчитывающий его характеристики. Поскольку разрешающая способность данных в пространстве и времени ограничена, мы избегаем дифференцирования поля скоростей.

Результаты исследований. Алгоритм протестирован на данных пациентов с двустворчатым аортальным клапаном и здоровых добровольцах. Приведены результаты для максимальных и осредненных по времени значений в аорте, легочной артерии, левом и правом желудочках.

Выводы. Результаты демонстрируют, что предложенный подход может быть полезным для медиков для классификации и диагностики разных патологий клапанов и сосудов.

Ключевые слова: четырехмерный поток; двухстворчатый клапан; течение в аорте; патологии сосудов.

Рекомендована Радою

факультету прикладної математики

КПI ім. Ігоря Сікорського
Надійшла до редакції

11 січня 2017 року 